\author{
Michał Drożdż \\ Uniwersytet Papieski Jana Pawła II w Krakowie \\ ORCID: 0000-0002-8448-7607
}

Klaudia Cymanow-Sosin

Uniwersytet Papieski Jana Pawła II w Krakowie

ORCID: 0000-0003-3248-9499

\title{
Monitoring programów informacyjnych na przykładzie nadawcy publicznego w aspektach etycznym i prawnym dotyczących misyjności i zawodu dziennikarskiego
}

\begin{abstract}
Streszczenie
Przedmiotem tego artykułu jest opis metodologii analizy zawartości pełnego monitoringu programu TVP Info w aspekcie misji mediów publicznych oraz etyczności w działaniach medialno-dziennikarskich. Szczegółowe badania programów informacyjnych zostały przeprouadzone w Akademickim Centrum Medialnym u Instytucie Dziennikarstwa i Komunikacji Społecznej na Wydziale Nauk Społecznych Uniwersytetu Papieskiego Jana Pawła II w Krakowie metodą badania tygodnia konstruowanego w zespole pod kierownictwem merytorycznym Michała Drożdża oraz kierownictuem uykonawczym Klaudii Cymanow-Sosin. Analiza zawartości została dodatkowo usparta wnioskami na podstawie ocen eksperckich w kontekście zasad etycznych i prawnych dotyczących zawodu dziennikarskiego oraz obowiązkóu misji nadawcy publicznego. Raport końcouy z monitoringu został opracowany w kontekście dwóch podstawouych faktorów ważnych dla funkcjonowania mediów, a mianowicie: misyjności mediów oraz etyczności działań medialno-dziennikarskich. Wnioski, jakie zostały sformułowane na podstawie tej części badań, są odpowiedzią na postawione pytanie o powinności nadaucy publicznego w etycznym i prawnym aspekcie dotyczącym zawodu dziennikarskiego.
\end{abstract}

Słowa kluczowe: analiza zawartości, etyka, media publiczne, misyjność mediów, telewizja.

\section{Monitoring news programmes on the example of a public station in the ethical and legal aspect related to the mission and the journalist profession}

Abstract

The subject matter of this article is the description of the methodology applied in the analysis of the content of the entire monitoring of the TVP Info station with regard to the mission of the public media and the ethical aspect in the actions of the media and the journalists. Detailed studies of the news programmes were conducted in the Academic Media Centre 
at the Institute of Journalism and Social Communication, at the faculty of Social Sciences of the Pontifical University of John Paul II in Krakow. The applied methodology involved a study of a week constructed within the team working under substantive supervision of Michał Drożdż and the executive supervision of Klaudia Cymanou-Sosin. The content analysis was additionally supported by conclusions drawn on the basis of expert evaluations in the context of ethical and legal principles pertaining to the journalist profession and the obligations related to the public mission of a public broadcaster. The final report from the monitoring was developed in the context of two basic factors important for the functioning of the media, namely: the mission of the media and the ethics of the actions of the media and the journalists. The conclusions that were formed on the basis of this part of the research are a response to the abovementioned question related to the obligations of the public broadcaster in the ethical and legal aspect pertaining to the journalist profession.

Keywords: content analysis, ethic, public media, media mission, television.

\section{Wprowadzenie}

Zagadnienie misyjności medióu publicznych można rozpatrywać z co najmniej dwóch odrębnych perspektyw, a mianowicie teoretycznej i praktycznej, czyli z perspektyuy aksjologii i etyki mediów, czerpiąc z dziedzictwa wypracowanego na gruncie polskich i zagranicznych studiów nad tą tematyką ${ }^{1}$ oraz z perspektywy samej praktyki dziennikarskiej. Na ustępie należałoby zdefiniouać pojęcie misyjności. Wstępnym założeniem jest fakt, że każdy dziennikarz ma prawo do własnych poglądów na świat, niemniej jednak proces uprowadzania w obieg publiczny wszystkich treści powinien odbywać się przy elementarnej świadomości misji medium, dla którego pracuje, a po wtóre - przy uwzględnieniu faktu, komu te treści mają ostatecznie służyć. Misyjność jest zatem rozumiana jako realizowanie określonych zadań i spełnianie funkcji dla dobra innych i dobra wspólnego. Jest to także niesienie i przekazywanie pewnych wartości, z profesjonalnym zaangażowaniem i co więcej - z powołaniem właściuym dla wykonywanego zawodu.

Jak zasygnalizowano w tekście Misyjność mediów - pomiędzy ideatem a iluzją ${ }^{2}$, misyjność mediów rozumiemy podwójnie: po pierwsze, to zadania i funkcje mediów w wymiarze społecznym o różnym charakterze: edukacyjnym, wychowawczym,

\footnotetext{
${ }^{1}$ Zob. P. Czarnecki, Etyka mediów, Wydawnictwo Difin, Warszawa 2008; M. Drożdż, Osoba i media. Personalistyczny paradygmat etyki mediów, Wydawnictuo Biblos, Tarnów 2005; M. Filipiak, Homo communicans. Wprowadzenie do teorii masowego komunikowania, Wydawnictwo Uniwersytetu Marii Curie-Skłodouskiej, Lublin 2003; M. Iłowiecki, Pilnowanie strażników. Etyka dziennikarska w praktyce, Wydawnictwo FRONDA, Warszawa 2012; M. McLuhan, Zrozumieć media. Przedłużenia człowieka, tłum. N. Szczucka, Wydawnictwa Naukowo-Techniczne, Warszawa 2004; A.W. Nowak, Podmiot, system, nowoczesność, Wydawnictwo IF UAM, Poznań 2011, J.A. Sobkowiak, Godność w komunikacji: communicatio, communicare, communitas, „Studia Theologica Varsaviensia” 2003, nr 2; J. Waszkiewicz, Od komunikacji do wspólnoty, Oficyna Wydawnicza Politechniki Wrocłauskiej, Wrocław 2002. 2 M. Drożdż, Misyjność mediów - pomiędzy ideałem a iluzją?, „Studia Socialia Cracoviensia” 2009, nr 1, s. 73-87.
} 
formacyjnym, kulturalnym, charytatyunym, ideologicznym, integracyjnym czy wreszcie ewangelizacyjnym. Są to także różnego typu działania mediów w zakresie spraw istotnych społecznie i aksjologicznie. Warto tu podkreślić, że misja społeczna i publiczna mediów, a ten artykuł jest poświęcony ułaśnie nadawcy publicznemu, jest czymś oczywistym, wynikającym z samej natury mediów. Te ostatnie są bouiem definiowane i traktowane jako środki społecznego komunikowania i potężne narzędzia, które mają siłę kształtowania uspółczesnej przestrzeni funkcjonowania człowieka.

Media są instytucjami, ale i instancjami stojącymi w centrum przestrzeni publicznej ludzi. Przedstawione tu spojrzenie na misyjność jest jednym z wielu. W zależności od przyjętych założeń misyjność może być różnie definiowana, interpretowana i upisywana w założenia, cele, struktury i funkcje różnych mediów, a przede uszystkim poszczególnych nadawców, którzy różnią się zarówno poglądami, jak i odmiennymi często założeniami wobec celów, jakie chcą osiągnąć. Cechą odróżniającą nadauców mediów mogą być także ich statusy i miejsca we uspółczesnym systemie medialnym. Misja jest odmiennie realizowana u zależności od tego, czy mamy do czynienia z mediami publicznymi, czy niepublicznymi, tj. nadawcami stacji komercyjnych i społecznych. Z obranej przez autorów perspektywy badawczej, ale też z praktyki dziennikarskiej wynika uprost, że uszyscy nadawcy funkcjonujący w przestrzeni publicznej, uszystkie media, ze swojej natury są misyjne jako narzędzia i instytucje komunikowania społecznego. Różnica u rodzaju tej misyjności uynika z tego i zależy od tego, jakie przekazy są wysyłane do użytkouników mediów, w jaki sposób się to odbywa, kto jest ostatecznym adresatem komunikatów, a także to, kiedy zachodzi proces komunikacyjny.

Przyjęciem takich założeń poszerzam pojęcie misyjności o wymiar negatyuny33. Nie można zaprzeczyć, że istnieje wiele mediów i programów, które z założenia oraz przyjętych celów i strategii nie wprowadzają w życie publiczne wartości pozytywnych. Takie założenie zmusza badacza do oddzielenia dwóch pojęć: misyjności u sensie ścisłym, które zakłada komunikowanie wartości dla dobra człowieka i uspólnoty, od takiego funkcjonowania mediów, które preferują w zdecydowanej mierze tylko korzyść ekonomiczną czy ideologiczną, co może się wiązać z przekraczaniem granic etycznych i naruszaniem zasady odpowiedzialności za dobro odbiorcy.

W drugim ze wspomnianych aspektów misyjność należy pojmować z perspektywy dziennikarskiej jako odpowiedzialne działanie dziennikarzy i uszystkich osób zaangażowanych w społeczne komunikowanie, czyli misję dziennikarską. Jeśli tak zostanie określona misyjność, to będzie ona w sposób nieunikniony ugruntowana na fundamencie odpowiedzialności dziennikarskiej. Odpowiedzialność zaś łączy się zausze z profesjonalnym i etycznym realizowaniem zawodu dziennikarza jako zawodu zaufania publicznego. Każdy dziennikarz, jako człowiek wykonujący swój zawód, mając prawo do własnych poglądów, do określonego poglądu na świat, równocześnie jednak - kiedy jakieś treści ma zamiar uprowadzać u obieg publiczny, za pośrednictuem określonego medium - winien czynić to z elementarną świadomością misji tego medium.

${ }_{3}^{3}$ Zob. Dobro w mediach. Z cienia do światta, red. A. Baczyński, M. Drożdż, Wydaunictuo BIBLOS, Tarnów 2012. 
Drugą czynnością, jak wydaje się niezbędną u procesie preselekcji, jest także i to, że dziennikarz winien - ujmując rzecz metaforycznie - przesiać swoje treści przez „sito” celowości, a więc zadać podstawowe pytanie: w jakim celu je komunikuje i czy będą one społecznie przydatne? Dodatkowe pytanie, jakie pouinno się pojawić, to kwestia: jaką wartość mają przekazywane komunikaty, a także - ostatnie z ważnych pytań - czemu ostatecznie służy ten przekaz? Dopiero odpowiedź na te pytania będzie punktem wyjścia u odpowiedzialnym realizowaniu misji dziennikarskiej, tak jak została ona zdefiniowana w tej publikacji.

\section{Pojęcie misyjności mediów i misji dziennikarskiej}

Oba sformułowania - misyjność mediów i misja dziennikarska - są korelatywne i komplementarne. Jakość samego dziennikarstua zależy u głóunej mierze od misyjności samych mediów. Nie można jednak tej zależności przeceniać i obciążać odpowiedzialnością tylko świata dziennikarzy za realizację misji publicznej i społecznej mediów. Stając niejako u obronie pojedynczych dziennikarzy, pracujących dla jakichś mediów, można stuierdzić, że misyjność mediów jest często poza zasięgiem dziennikarzy, gdyż zależy ona od struktur właścicielsko-instytucjonalnych, struktur decydenckich, wynika z założonych celów programouych i funkcjonalnych mediów oraz ze sprzężenia mediów ze sferą komercji i polityki. Oznaczałoby to, że czynniki tkwiące poza postacią samego dziennikarza warunkują ostatecznie komunikat, który jest eksponowany w mediach.

Niemniej jednak dziennikarze winni z całą świadomością i odpowiedzialnością dbać o to, na miarę swoich możliwości, by media, w których działają, upisywały się od strony strukturalnej i programowej w budowanie, a nie niszczenie wartości. Rozważając $w$ licznych debatach, także $w$ trakcie corocznie odbywających się konferencji w zakresie „Etyki Mediów”, zarówno teoretycy, jak i praktycy stwierdzają, że skrajną, ale i konieczną niekiedy reakcją na zmianę linii redakcyjnej medium, o której nagle zdecydowaliby decydenci, powinna być rezygnacja z firmowania własnym nazwiskiem danego tytułu prasowego, programu radiowego czy telewizyjnego lub przekazu u internecie. Niezuykle istotną kwestią jest to, by dziennikarze funkcjonowali i działali w takich strukturach medialnych, które będą spójne z ich światem wartości. Nie jest to sprawa łatua w praktyce, dziennikarze mają bowiem także prawo do zmiany poglądów, a z psychologicznego punktu widzenia upływ środowiskowy jest ważnym czynnikiem ingerującym $w$ nasze pojmowanie rzeczywistości.

Z czasem zatem uczestnictuo u działalności jakiegoś medium może wywierać tak silne działanie na dziennikarza, że wyznawane przez niego wartości stapiają się niejako z linią samego medium. Zasadą, którą należy przyjąć u ocenie tego zjawiska, jest zapewne jednak guarancja realizacji misji dziennikarskiej na podstawie własnego sumienia. Co więcej, dziennikarz winien założyć, że powinien być także elementarnie uczciwy. Chodzi o to, by swoim działaniem nie stawał niejako „w poprzek” misyjności, czyli by nie niszczył pozytywnych wartości i nie przeszkadzał w realizacji misyjnych 
założeń medium, u którym się dziennikarsko angażuje. Pluralizm mediów powinien dawać możliwość odnajdywania się dziennikarzy o różnym zakorzenieniu aksjologiczno-światopoglądouym, a także różnych wizjach misji społecznej mediów.

W odniesieniu do przeprowadzonych badań należy założyć, że dziennikarze winni realizować swoją profesję dziennikarską zgodnie z misją dziennikarską: profesjonalnie, a więc trzeba dodać, że również etycznie. Nie może to jednak uykluczać działalności zgodnej ze specyfiką misujności medium, w którym działają. Te myśli stanowią punkt wyjścia do podjętych analiz, a zarazem uskazują na istniejący dylemat misyjności mediów. Nasuwa się bowiem pytanie, gdzie i jaki jest zatem ideał, a gdzie iluzja misyjności u tym podwójnym znaczeniu, które zostało tu opisane. Niniejszy artykuł, będący teoretycznym uogólnieniem $\mathrm{w}$ odniesieniu do monitoringu programu TVP Info, skupia się głównie na zadaniach dotyczących misyjności mediów w kontekście potrzeby szacunku dla wartości i godności każdego człowieka.

\section{Status zawodu dziennikarza w kontekście misyjności}

Drugim faktorem stanowiącym podstawowy punkt odniesienia $w$ przygotowaniu analizy zawartości programów nadawcy publicznego w kontekście realizacji przez niego nałożonej misji jest określenie statusu zawodowego dziennikarza. Zawód dziennikarza upisuje się w społeczeństwach demokratycznych w szerokie pojęcie wolności wypowiedzi, ta zaś uynika z wolności człowieka i samej istoty społeczeństua obywatelskiego. Dlatego też uszelkie próby warunkowania pracy dziennikarskiej i określania statusu dziennikarza mogą być traktowane jako zamach na wolność słowa i wolność demokratycznego społeczeństwa. Takie jednostronne rozumienie działań wobec osób wykonujących ten zawód byłoby jednak daleko idącym uproszczeniem. Nie można mieć bowiem wątpliwości, że status i praca dziennikarza są określone i uwarunkowane wieloma czynnikami. Mają one suoją specyfikę działań, a dziennikarz posiada swoją tożsamość zawodową. Poustaje zatem kolejne pytanie, czy i gdzie ma uzasadnienie pewność tego tuierdzenia.

Monitoring, opracowany w Akademickim Centrum Medialnym działającym w Instytucie Dziennikarstwa i Komunikacji Społecznej na Wydziale Nauk Społecznych Uniwersytetu Papieskiego Jana Pawła II w Krakowie, a także unioski, jakie poustały na gruncie przeprowadzonych badań, stanowią próbę poszukiwania odpowiedzi na to pytanie z perspektywy etyki dziennikarstwa (przedmiotowe ujęcie) i etyki dziennikarskiej (podmiotowe ujęcie), ponieważ ta przestrzeń etycznej refleksji nad pracą dziennikarza stanowi właściwy kontekst odkrywania statusu dziennikarza. Świadczą o tym uszelkie wysiłki prawne, instytucjonalne, kontrolne, regulowanie i monitorowanie pracy dziennikarzy, które zasadniczo posiłkują się refleksją i odniesieniami etycznymi, w których z kolei ujawnia się specyfika misji dziennikarskiej.

Wyniki z prowadzonych analiz pokazują niezbicie, że niezasadna jest ucieczka od terminologii misji dziennikarskiej, gdyż jest ona integralnie upisana w etyczność zawodu 
dziennikarza i prawne regulacje jego zadań, opartych na prawach i powinnościach zawodowych. Status dziennikarza i jego działania wypływają u zasadniczym wymiarze z etycznych uwarunkowań tej profesji. Środowiska ludzi mediów dysponują bowiem, szczególnie dzisiaj w dobie medialnego postępu technologicznego, ogromnym potencjałem oddziaływania na ludzi. Źle wykorzystany potencjał może - na co uskazuje doświadczenie i obserwacja świata mediów - przynieść ogromne szkody moralne i społeczne. Dlatego warto podejmować dyskurs nad statusem dziennikarza z perspektywy etyczności pracy dziennikarzy i ludzi mediów, który określa u zasadniczych ramach przestrzeń misji dziennikarskiej.

Ujmowanie tego zagadnienia z takiej właśnie perspektyuy wydaje się zasadne z racji różnorodnych procesów, którym podlegają uspółczesne media, a tym samym status dziennikarza. Etyczny uymiar pracy dziennikarza zdaje się nadążać za tymi zmianami i dostarczać właściuych odpowiedzi do rozwiązywania nowych dylematów dotyczących profesji dziennikarskiej, w której kategorie etyczne stanowią priorytetową podstawę wartościowania, ocen i kierunków zewnętrznych regulacji mediów i pracy dziennikarza. Wartą przytoczenia jest myśl z dokumentu Etyka w środkach społecznego przekazu Papieskiej Rady d/s Środków Społecznego Przekazu z roku 2000, która może stanowić ilustrację tezy o konieczności poszukiwania podstaw, określających status i misję dziennikarza w przestrzeni etycznej. Twórcy dokumentu wyrażają przekonanie, że

rozwiązanie problemów wynikłych z tej nieuregulowanej komercjalizacji i prywatyzacji [mediów] nie polega jednak na kontroli państwa nad mediami, lecz na szerszej regulacji, zgodnej z normami służby publicznej, jak i na możliwie największej odpowiedzialności publicznej. W związku z tym należy zwrócić uwagę, że o ile ramy prawne i polityczne, w jakich funkcjonują media w niektórych krajach, doczekały się uyraźnej poprawy, to jednak istnieją jeszcze miejsca, gdzie interwencja rządowa pozostaje narzędziem ucisku i wykluczenia ${ }^{4}$.

W innym punkcie Etyki w środkach społecznego przekazu Rada uspomina, iż

należy zawsze popierać wolność wyrazu opinii, gdyż ludzie idący za swoją naturalną skłonnością do wyrażania własnych poglądów, dzielenia się własnymi opiniami i wreszcie wymiany myśli, przyczyniają się nie tylko do osobistego rozwoju, ale także uspierają rozwój całych społeczności. Można dodać, że korzystając ze swoich praw, spełniają także obowiązek wobec społeczeństua. Wszakże to założenie rozpatrywane u perspektywie etycznej nie stanowi normy absolutnej i niezmiennej. Istnieją oczywiste przypadki: zniesławienie, oszczerstuo, kalumnia, podżeganie do nienawiści i konfliktów między jednostkami i grupami, formy obscenii i pornografii, chorobliwe obrazy przemocy, będące przedmiotem wielu analiz w ostatnich latach mowa nienawiści - gdzie nie obowiązuje żadne prawo do ich przekazywania. Równie pewne jest to, że prawo do wolnego przekazywania opinii winno zausze respektować takie zasady, jak prawda, sprawiedliwość i poszanowanie życia prywatnego ${ }^{5}$.

${ }^{4}$ Papieska Rada d/s Środków Społecznego Przekazu, Etyka w środkach społecznego przekazu, Watykan 2000, nr 21.

${ }^{5}$ Ibidem, nr 23. 
Takie etyczne ujęcie uwarunkowań dziennikarskiej realizacji wolności uypowiedzi świadczy o tym, że praca dziennikarza jest nie tylko prostym wypełnianiem powinności zawodowych wynikających z wielorakiej funkcjonalności mediów, ale zawiera w sobie szczególną potrzebę respektowania wolności i praw osób, do których przekaz dziennikarski dociera, uprowadzony pracą dziennikarza u przestrzeń publiczną. Ten fakt stanowi podstawę tego, co możemy określić misyjnością pracy dziennikarza. Warto przy tym zauważyć, że o misyjności możemy mówić u sposób właściuy tylko w kontekście etycznym. Poza tym kontekstem „misyjność” traci swój sens.

Podsumourując rozuażania nad misyjnością zawodu dziennikarza należy stwierdzić, że pojęcie to jest w ostatnich latach przedmiotem częstego, uręcz lekceważącego banalizowania czy ironicznych uwag. Wsłuchując się w dyskurs publiczny, wielokrotnie na pytanie o misyjność tego zawodu można usłyszeć odpowiedź, że dziennikarz nie powinien pełnić jakiejś szczególnej misji, ale solidnie i rzetelnie wypełniać swoje dziennikarskie zadania. Tego typu ujęcia czy zastępcze sformułowania misji dziennikarskiej nie przekreślą istoty statusu dziennikarza i jego zadań wynikających z funkcjonalności społecznej mediów. Jakkolwiek nazwiemy pracę dziennikarza: realizacją misji, wypełnianiem obowiązków zawodowych, zaspokajaniem prawa ludzi do bycia informowanym, spełnianiem oczekiwań społecznych, wykonywaniem zadań zawodu zaufania publicznego itd., nie zanegujemy istoty zawodu dziennikarza, znajdującej swoje odzwierciedlenie w różnych regulacjach prawnych, regulaminowych, a przede wszystkim etycznych.

\section{Powinności dziennikarza wobec obywateli i społeczeństwa w aspekcie etycznym}

Istotną przestrzenią uypełniania misji publicznej mediów i powinności dziennikarza jest edukacja obywatelska, która się realizuje przede uszystkim w programach informacyjnych i publicystycznych, do których należy analizowany program TVP Info. Realizacja tych zadań traktowana jest także w dokumentach prawnych i etycznych jako obowiązek zawodowy i powinność etyczna.

Świadczą o tym odniesienia do omawianego zagadnienia, jakie zostały zawarte, po pierwsze, $w$ Ustawie o radiofonii i telewizji ${ }^{6}$ w tekście ujednoliconym w 2015 roku w art. 1. ustęp 1, pkt 3a, w których stwierdzono, że zadaniem radiofonii i telewizji jest upouszechnianie edukacji obywatelskiej. To zadanie obejmuje uszystkie podmioty. W ustępie 1a czytamy:

Zadania radiofonii i telewizji, o których mowa u ust. 1, są realizowane przez dostarczanie usług medialnych. W art. 13 czytamy: Nadawca kształtuje program samodzielnie w zakresie zadań określonych w art. 1 ust. 1 i ponosi odpowiedzialność za jego treść. Można zatem uznać, że to zadanie edukacji obywatelskiej jest powinnością uszystkich podmiotów dostarczających usługi medialne. Jaki jest zakres tej edukacji? Ustawa próbuje definiować zakres edukacji

${ }^{6}$ Ustawa z dnia 29 grudnia 1992 r. o radiofonii i telewizji, Dz.U. z 1993 roku Nr 7, poz. 34. 
obywatelskiej odnosząc go bezpośrednio do zadań mediów publicznych. Art. 21: Publiczna radiofonia i telewizja realizuje misję publiczną, oferując, na zasadach określonych w ustawie, całemu społeczeństuu i poszczególnym jego częściom, zróżnicowane programy i inne usługi w zakresie informacji, publicystyki, kultury, rozrywki, edukacji i sportu, cechujące się pluralizmem, bezstronnością, wyważeniem i niezależnością oraz innowacyjnością, wysoką jakością i integralnością przekazu?

Artykuł 21 uszczegóławia zakres tych zadań, które możemy zaliczyć do edukacji obyuatelskiej. W ustępie 2 w punkcie 2, 3 i 4.2 czytamy:

Programy i inne usługi publicznej radiofonii i telewizji powinny: 2) rzetelnie ukazywać całą różnorodność uydarzeń i zjawisk u kraju i za granicą; 3) sprzyjać swobodnemu kształtowaniu się poglądów obywateli oraz formowaniu się opinii publicznej; 4) umożliwiać obywatelom i ich organizacjom uczestniczenie w życiu publicznym poprzez prezentowanie zróżnicowanych poglądów i stanouvisk oraz uykonywanie prawa do kontroli i krytyki społecznej.

Powinność edukacji obywatelskiej jest zatem zadaniem upisanym u normatyuność prawną. Edukacja obywatelska jest częścią zarówno zadań mediów w ramach tak zwanych usług medialnych oraz częścią misji publicznej, będącej bezpośrednią powinnością ustawową mediów publicznych. Te zadania wynikają ze szczegółowo analizowanych zapisów Ustawy o Radiofonii i Telewizji.

Po drugie, należy uspomnieć Rezolucję 1003 Zgromadzenia Parlamentarnego Rady Europy z 1 lipca $1993^{9}$ roku w sprawie etyki dziennikarskiej, która zawiera już u art. 1 odniesienia do edukacji obywatelskiej.

W nawiązaniu do ustawowych praw i obowiązków zawartych w szczegółouyych unormowaniach prawnych, media mają etyczną odpowiedzialność w stosunku do obywateli i społeczeństua, która musi być wyeksponowana w obecnych czasach, kiedy to informowanie i komunikowanie odgrywają tak bardzo istotną rolę w kształtowaniu postaw obywateli, w rozwoju społeczeństwa i demokratycznych struktur ${ }^{10}$.

Narzędziem i sposobem edukacji obywatelskiej jest zatem, po pierusze (1), rzetelne przekazywanie informacji, które według tej rezolucji (pkt 4) powinno być oparte na praudzie, popartej stosouną weryfikacją i udokumentowaniem zebranych materiałów, bezstronnością przekazu zarówno w prezentacji, opisie, jak i narracji. Po drugie, (2) edukacja obywatelska realizuje się także poprzez medialne opinie (pkt 5), które dotyczą ocen lub komentarzy na temat aktualnych wydarzeń w formie ogólnych uwag, pomysłów, ocen. Chociaż opinie są z natury subiektywne i nie mogą być utożsamiane z pojęciem prawdy, to jednak należy żądać, aby wypowiadane opinie były uczciue i etyczne. (pkt 6) Opinie [...] nie powinny zaprzeczać lub fałszować rzeczywistych faktów

\footnotetext{
7 Ibidem.

${ }^{8}$ Ibidem.

${ }^{9}$ Por. Rezolucja 1003 Zgromadzenia Parlamentarnego Rady Europy z dnia 1 lipca 1993 roku w sprawie etyki dziennikarskiej, „Zeszyty Prasoznawcze” 1994, nr 3-4, s. 155-160.

${ }^{10}$ Ibidem.
} 
i danych. Opinie też muszą być uczciue! Dokument Zgromadzenia Parlamentarnego Rady Europy przenosi zatem zadania edukacji obywatelskiej realizowanej poprzez informacje i opinie na poziom powinności etycznej. Media mają, jak jest napisane:

etyczną odpowiedzialność w stosunku do obywateli i społeczeństwa, (pkt 17) informowania i komunikowania, które przekazywane przez dziennikarzy uszystkich mediów, ze znaczącym wsparciem ze strony nouych technologii, ma niezuykłe znaczenie dla rozwoju jednostki i społeczeństua. Jest niezbędnym warunkiem demokracji, bo pełna demokracja uymaga gwarantowania obywatelom uczestnictwa w sprawach publicznych. Należy zaznaczyć, że takie uczestnictwo byłoby niemożliwe, jeżeli obywatele nie mieliby dostępu do informacji dotyczących spraw publicznych, której potrzebują, a która powinna być dostarczana im przez media ${ }^{11}$.

Po trzecie, Deklaracja Zasad Międzynarodowej Federacji Dziennikarzy z 1989 roku $^{12}$ już u punkcie pieruszym stuierdza:

Szacunek dla prawdy i prawa obywateli do poznania prawdy jest podstawowym obowiązkiem dziennikarza. (pkt 2) Spełniając ten obowiązek dziennikarz powinien zausze bronić zasad wolności poprzez rzetelne zbieranie i publikowanie informacji, a także bronić prawa do uczciuego komentowania i krytyki ${ }^{13}$.

Deklaracja ta uskazuje na powinność etyczną dziennikarzy realizowania podstawowego prawa obywateli do poznania prawdy. Dziennikarz ma prawo do własnych poglądów, do swojego światopoglądu, niemniej jednak cokolwiek wprowadza w obieg publiczny, poprzez określone media, powinien czynić z elementarną świadomością misji tego prawa do prawdy i powinności przekazywania prawdy.

Czwarty tekst, na który należy się powołać u tym kontekście, to uspomniany już

dokument Papieskiej Rady ds. Środków Społecznego Przekazu wydany w roku 2000 pt. Etyka w mediach. Zadania z obszaru edukacji obywatelskiej definiowane są w nim w następujący sposób:

(nr 8) Przekaz społeczny służy społeczeństuu, ułatwiając świadomy udział obywateli w procesie politycznym. Środki społecznego przekazu jednoczą ludzi w osiąganiu uspólnych celów i zadań, pomagając im u ten sposób kształtować i podtrzymywać autentyczne wspólnoty polityczne. Środki społecznego przekazu są niezbędne dla dzisiejszych społeczeństw demokratycznych. Zapewniają informacje na temat problemów i wydarzeń. Pozwalają liderom porozumiewać się natychmiast i bezpośrednio z obywatelami w pilnych kwestiach. Są ważnymi narzędziami kształtowania odpowiedzialności, ponieważ wykazują niekompetencję,

\footnotetext{
${ }^{11}$ Ibidem.

${ }^{12}$ II Śuviatouy Kongres Międzynarodowej Federacji Dziennikarzy, który odbył się u Bordeaux (25-28 kwietnia 1954 r.) uchwalił Deklarację Zasad Międzynarodowej Federacji Dziennikarzy (tekst z poprawkami uniesionymi podczas XVIII Światowego Kongresu FU w Helsinkach 2-6 czeruca 1989 r.).

${ }^{13}$ Ibidem.
} 
korupcję i nadużycia, zuracając uwagę na potrzebę kompetencji, ducha obywatelskiego i oddania się obowiązkom ${ }^{14}$.

Język tego dokumentu nie ma charakteru normatywnego, ale w tym opisie zadań mediów i dziennikarzy mieści się powinność etyczna takiego tuorzenia mediów, które będą służyć dobru osoby i uspólnoty.

Kolejne uskazanie zawarte jest w Karcie Etycznej Mediów w Polsce, podpisanej 29 marca 1995 roku $^{15}$, w której to w preambule dokumentu stanowiącego najważniejszy kodeks etyczny mediów w Polsce czytamy:

Dziennikarze, wydawcy, producenci i nadawcy, szanując niezbywalne prawo człowieka do prawdy, kierując się zasadą dobra uspólnego, świadomi roli mediów w życiu człowieka i społeczeństua obywatelskiego, przyjmują tę kartę oraz deklarują, że w swojej pracy kierować się będą następującymi zasadami. Znamy te zasady, ale pozwolimy sobie uymienić zasadę szóstą, która uskazuje na nieosiągalny ideał: (pkt 6) zasada pieruszeństua dobra odbiorcy - co znaczy, że podstawowe prawa czytelników, widzów i słuchaczy są nadrzędne wobec redakcji, dziennikarzy, uydauców, producentów i nadawców ${ }^{16}$.

Można stwierdzić, że ta zasada etyczna uskazuje na potrzebę i konieczność realizacji funkcji medialnych w duchu powinności etycznej troski o dobro odbiorców. Jest to uszakże bardzo idealistyczny cel.

Przedostatni z dokumentów, który stanowił fundament teoretyczny w trakcie przygotowań do prowadzenia analizy zwartości programów nadawcy publicznego, to jest Kodeks Etyki Dziennikarskiej z 13 października 2001 roku ${ }^{17}$, gdzie już we ustępie uskazuje się na zadania dziennikarzy i mediów upisujące się w zakres tego, co wcześniej zostało określone jako edukacja obywatelska. Przyjmując zasady Karty Etycznej Mediów i deklaracji Międzynarodowej Federacji Dziennikarzy, uznajemy, że: (1) zadaniem dziennikarzy jest przekazywanie rzetelnych i bezstronnych informacji oraz różnorodnych opinii, a także umożliwianie udziału u debacie publicznej, (2) wolności słowa i wypowiedzi musi towarzyszyć odpowiedzialność za publikacje u prasie, radiu, telewizji czy internecie, (3) dobro czytelników, słuchaczy i widzów oraz dobro publiczne powinny mieć pieruszeństwo wobec interesów autora, redaktora, wydawcy lub nadawcy.

\footnotetext{
${ }^{14}$ Ibidem.

${ }^{15}$ Karta Etyczna Mediów u Polsce została podpisana 29 marca 1995. Kartę Etyczną Medióu, opracowaną z inicjatyuy Stowarzyszenia Dziennikarzy Polskich, podpisali w dniu 29 marca 1995 roku prezesi: Stowarzyszenia Dziennikarzy Polskich, Stowarzyszenia Dziennikarzy Rzeczpospolitej Polskiej, Katolickiego Stowarzyszenia Dziennikarzy, Syndykatu Dziennikarzy Polskich, Związku Zawodowego Dziennikarzy, Unii Wydawców Prasy, Telewizji Polskiej S.A., Telewizji „Polsat”, Stowarzyszenia Niezależnych Producentów Filmowych i Telewizyjnych, Polskiego Radia S.A., Stowarzyszenia Radia Publicznego u Polsce, Stowarzyszenia Polskiej Prywatnej Radiofonii, Związku Zawodowego Dziennikarzy Radia i Telewizji oraz krajouy duszpasterz środowisk twórczych, ks. Wiesław Niewęgłouski, centruminformacji.tvp.pl (dostęp: 05.02.2019). ${ }^{16}$ Ibidem.

${ }_{17}$ Kodeks Etyki Dziennikarskiej z 13 października 2001 roku, http://wuw.krrit.gov.pl/Data/ Files/_public/pliki/publikacje/analiza2006_07.pdf (dostęp: 15.01.2019).
} 
W katalogu uskazań, wynikających z dokumentów, które odnoszą się do zawodu dziennikarza, ostatnim we wspomnianych jest zestaw Zasad etyki dziennikarskiej w Telewizji Polskiej S.A. - informacja, publicystyka, reportaż, dokument, edukacja u aktualnej wersji z 2019 roku $^{18}$. Preambuła do tego dokumentu określa zasady misji dziennikarzy u telewizji publicznej u sposób jednoznaczny:

dziennikarstwo w Telewizji Polskiej S.A. realizuje idee służby publicznej oparte na rzetelności, uczciwości, bezstronności i obywatelskiej urażliwości, a także na najlepszych wzorcach i standardach warsztatowych. Wartości te wyznaczają dziennikarzom telewizji publicznej sposób postępowania zawodowego ${ }^{19}$.

\section{Podsumowanie}

Starając się przygotować teoretyczne podstawy monitoringu mediów nie można pominąć - zamieszczonych w tym artykule - rozważań dotyczących etyki mediów i etyki zawodu dziennikarza. Jest to dla badaczy sfery aksjologicznej obszar fundamentalny, bez którego analiza ilościowa okazałaby się nieużyteczna interpretacyjnie. Drugim filarem, na którym została stworzona metoda badania programów informacyjnych na potrzeby przeprowadzanego monitoringu, jest aspekt prawny. Konstruując zestaw uwag metodologicznych do konstrukcji uniosków z raportu, bazowano na kontekstach zasad etycznych i prawnych zawodu dziennikarskiego uwzględnionych w następujących dokumentach:

- Deklaracja Zasad Międzynarodowej Federacji Dziennikarzy IFJ z 6 czeruca 1989 roku;

- Karta Etyczna Mediów Polskich z 29 marca 1995 roku;

- Kodeks Etyki Dziennikarskiej Stowarzyszenia Dziennikarzy Polskich z 13 października 2001 roku;

- Dziennikarski Kodeks Obyczajowy Stowarzyszenia Dziennikarzy Rzeczpospolitej Polskiej z 27 urześnia 1991 roku;

- Ustawa o Prawie Prasouym z 26 stycznia 1984 roku z późniejszymi poprawkami;

- Rezolucja 1003 Zgromadzenia Parlamentarnego Rady Europy z 1 lipca 1993 roku w sprawie etyki dziennikarskiej;

- Ustawa o radiofonii i telewizji w tekście ujednoliconym z dnia 29 grudnia 1992 roku z poprawkami od 2 października 2015 roku;

- Etyka w środkach społecznego przekazu Papieskiej Rady d/s Środków Społecznego Przekazu z 4 czerwca 2000 roku;

- Zasady etyki dziennikarskiej w Telewizji Polskiej S.A. - informacja, publicystyka, reportaż, dokument, edukacja u aktualnej wersji z 2019 roku.

${ }_{18}$ Zasady etyki dziennikarskiej $w$ Telewizji Polskiej S.A. - informacja, publicystyka, reportaż, dokument, edukacja w aktualnej wersji z 2019 roku, https://s.tvp.pl/repository/attachment/0/e/e/0eea386c0fa98ad0c49f73f1a9f7c8e71445347977947.pdf (dostęp: 15.01.2019).

${ }^{19}$ Ibidem. 
Jak uskazują szczegółowe wyniki zamieszczone w artykule: Analiza zawartości przekazów telewizyjnych w programach informacyjnych na przykładzie monitoringu TVP Info ${ }^{20}$, profesjonalizm dziennikarski nie jest jednak tylko kwestią warsztatową. Jego integralną częścią jest etyczność działań dziennikarskich, które w polskich i międzynarodouych kodeksach etyki dziennikarskiej, również u Telewizji Polskiej, wyznaczają wysokie standardy profesjonalizmu dziennikarskiego, do którego uszyscy dziennikarze muszą sięgać i nim się uykazywać w codziennej pracy. Jak czytamy bowiem w Deklaracji Zasad Międzynarodowej Federacji Dziennikarzy, dziennikarz godny tego miana powinien uważać za swój obowiązek przestrzeganie zasad etyki dziennikarskiej.

\section{Bibliografia}

Cymanow-Sosin K., Drożdż M., Analiza zawartości przekazów telewizyjnych w programach informacyjnych na przykładzie monitoringu TVP Info, „Media Biznes Kultura” 2019, nr 6, s. 20-39.

Czarnecki P., Etyka mediów, Wydawnictuo Difin, Warszawa 2008.

Deklaracja Zasad Międzynarodowej Federacji Dziennikarzy.

Dobro w mediach. Z cienia do światła, red. A. Baczyński, M. Drożdż, Wydawnictuo BIBLOS, Tarnów 2012.

Drożdż M., Misyjność mediów - pomiędzy ideałem a iluzją?, „Studia Socialia Cracoviensia” 2009, nr 1, s. 73-87.

Drożdż M., Osoba i media. Personalistyczny paradygmat etyki mediów, Wydaunictuo BIBLOS, Tarnów 2005.

Filipiak M., Homo communicans. Wprowadzenie do teorii masowego komunikowania, Wydawnictwo Uniwersytetu Marii Curie-Skłodouskiej, Lublin 2003.

Iłowiecki M., Pilnowanie strażników. Etyka dziennikarska w praktyce, Fronda, Warszawa 2012.

Karta Etyczna Mediów, centruminformacji.tvp.pl (dostęp: 05.02.2019).

Kodeks Etyki Dziennikarskiej z 13 października 2001 roku, http://wuw.krrit.gov.pl/Data Files/_public/pliki/publikacje/analiza2006_07.pdf (dostęp: 15.01.2019).

McLuhan M., Zrozumieć media. Przedłużenia człowieka, tłum. N. Szczucka, Wydawnictua Naukowo-Techniczne, Warszawa 2004.

Nowak A.W., Podmiot, system, nowoczesność, Wydawnictwo UAM, Poznań 2011.

Papieska Rada d/s Środków Społecznego Przekazu, Etyka w środkach społecznego przekazu, Watykan 2000, nr 21-23.

Rezolucja 1003 Zgromadzenia Parlamentarnego Rady Europy z dnia 1 lipca 1993 roku w sprawie etyki dziennikarskiej, „Zeszyty Prasoznawcze” 1994, nr 3-4, s. 155-160.

Sobkowiak J.A., Godność w komunikacji: communicatio, communicare, communitas, „Studia Theologica Varsaviensia" 2003, nr 2.

Ustawa z dnia 29 grudnia 1992 r. o radiofonii i telewizji, Dz.U. z 1993 roku Nr 7, poz. 34.

${ }^{20}$ K. Cymanow-Sosin, M. Drożdż, Analiza zawartości przekazów telewizyjnych w programach informacyjnych na przykładzie monitoringu TVP Info, „Media Biznes Kultura” 2019. 
Monitoring programów informacyjnych...

Waszkiewicz J., Od komunikacji do wspólnoty, Oficyna Wydaunicza Politechniki Wrocłauskiej, Wrocław 2002.

Zasady etyki dziennikarskiej w Telewizji Polskiej S.A. - informacja, publicystyka, reportaż, dokument, edukacja w aktualnej wersji z 2019 roku, https://s.tvp.pl/repository/attachment/ 0/e/e/0eea386c0fa98ad0c49f73f1a9f7c8e71445347977947.pdf (dostęp: 15.01.2019). 